\title{
SEASONAL CHANGES IN DIET OF GYRFALCONS NESTING AT ELLESMERE ISLAND AND OTHER HIGH ARCTIC LOCATIONS
}

\author{
TOM J. CADE ${ }^{1}$ AND DAVID M. BIRD ${ }^{2}$ \\ ${ }^{I}$ The Peregrine Fund, 5668 West Flying Hawk Lane, \\ Boise, ID 83709, USA.E-mail: tcade@peregrinefund.org \\ ${ }^{2}$ Avian Science and Conservation Centre of McGill University, 2111Lakeshore Road, \\ Ste. Anne de Bellevue, Quebec, Canada
}

\begin{abstract}
Gyrfalcons (Falco rusticolus) breeding in the High Arctic Canadian Islands and in northern Greenland have available to them widely scattered nesting sites on cliffs throughout much of this region, but their food resources are limited to four principal species, Rock Ptarmigan (Lagopus muta), Snow Bunting (Plectrophenax nivalis), Collared Lemming (Dicrostonyx torquatus), and Arctic Hare (Lepus arctica), with seabirds, waterfowl, and shorebirds playing a role in some localities. The distribution and abundance of these principal prey are highly variable in time and space, and consequently the serviceability of eyries is unpredictable and largely determined by the abundance of food in a particular year. Most Gyrfalcon populations depend on an abundance of ptarmigan (Lagopus spp.) for their food during the critical period of establishing a pairbond and laying eggs in late winter (mid-April and May in the High Arctic). Ptarmigan are now rather sparse in the High Arctic and apparently seldom build up to numbers that can support Gyrfalcon reproduction without supplementation by other prey. Where the Collared Lemming occurs and reaches "peak" numbers in some years, it apparently serves as a substitute, abetted by whatever ptarmigan are available. Early spring flocks of male Snow Buntings may also help. Whether or not Gyrfalcons can exploit adult hares effectively at this time remains a question that needs study. At the time female gyrs are incubating eggs in late May and June, the leverets of Arctic Hare become available, and Gyrfalcons utilize them heavily where they are common. Lemmings, if they survive into the summer, and leverets can support falcon reproduction through the nestling period into August. During migration in late August and on into September and October, the juvenile falcons feed heavily on the large flocks of young Snow Buntings. In special situations, large breeding colonies of Dovekies (Alle alle) provide the bulk of food during the nestling period of the falcons. The principal herbivores included in these trophic relationships - ptarmigan, lemming, and hare - fluctuate drastically in numbers from year to year and may have "cyclic" peaks ranging in interval from four to 11 years depending on species and locale. The correspondence of peak years in two or more of these species may strongly influence successful reproduction by Gyrfalcons and may account for the spectacular fall movements of falcons formerly reported in NE Greenland. Evidence is growing that the amplitude of these "cycles" has been decreasing and their periodicity increasing or breaking down under the influence of climate change. Gyrfalcon populations might well decline under these circumstances. The strong dependence of the High Arctic gyrs on maritime and marine birds for their winter food could also be jeopardized if the arctic sea ice continues to melt and disappears as currently predicted. Received 11 July 2011, accepted 22 August 2011.
\end{abstract}


CADE, T. J., AND D. M. BIRD. 2011. Seasonal changes in diet of Gyrfalcons nesting at Ellesmere Island and other high Arctic locations. Pages 355-370 in R. T. Watson, T. J. Cade, M. Fuller, G. Hunt, and E. Potapov (Eds.). Gyrfalcons and Ptarmigan in a Changing World, Volume I. The Peregrine Fund, Boise, Idaho, USA. http://dx.doi.org/10.4080/gpcw.2011.0401

Key words: High Arctic, trophic relations, climate change, Gyrfalcon, Rock Ptarmigan, Snow Bunting, Collared Lemming, Arctic Hare, marine birds.

IT IS BECOMING INCREASINGLY CLEAR that the white Gyrfalcons (Falco rusticolus) breeding on Ellesmere Island and adjacent Canadian High Arctic Islands have a rather unique life history that is strongly influenced by the presence of substantial populations of the Arctic Hare (Lepus arcticus) in this region. In most parts of their circumpolar breeding range Gyrfalcons feed mainly on Willow Ptarmigan (Lagopus lagopus) and/or Rock Ptarmigan (Lagopus muta), and the abundance of ptarmigan in the early stages of the breeding cycleat least up to hatching-determines whether or not breeding will occur and be successful in any given year, although bad weather can also be an intervening factor (Nyström et al. 2005, Koskimies and Sulkava 2011, Mossop 2011, and Nielsen 2011, in this volume). This dependence on ptarmigan in the early season appears to apply even to pairs that later have the opportunity to switch to alternate prey for feeding their young (seabirds at coastal eyries and hares, lemmings, waterfowl, shorebirds, and songbirds at inland locales).

Rock Ptarmigan are generally scarce on Ellesmere Island and are not known to reach periodic high numbers, at least in recent decades, as they do, or did, in other parts of their range, and there are no colonial nesting alcids there. Other than Arctic Hares and Collared Lemmings, potential prey species are rather limited in kind and numbers. Parmelee and MacDonald (1960) found 23 species of birds on the Fosheim Peninsula of Ellesmere, and Muir and Bird (1984) considered only eight of them abundant enough to serve as significant sources of food for the falcons (Table 1 ), as well as three species of mammals, Arctic
Hare, Collared Lemming, and Short-tailed Weasel (Mustela erminea). Kits of the Arctic Fox (Vulpes lagopus) could also be potential prey (Booms and Fuller 2003), but none were seen when the gyrs were observed nesting in 1973 (Muir and Bird 1984).

Using information from the published literature, from an unpublished report by Dalton Muir ("A study of the breeding biology of Arctic Gyrfalcons," circa 1975) to the Canadian Wildlife Service, studies of food habits at two eyries (Muir and Bird 1984, BBC film 2008 "White Falcon, White Wolf"), and other sources, we attempt to construct a plausible annual cycle of changes in the diet of Gyrfalcons on Ellesmere Island and other High Arctic locations and to hypothesize how these northernmost falcons manage to breed successfully, in some years, in the apparent absence of an abundance of ptarmigan at the beginning of the breeding season. The main reason an answer to this question is so hard to obtain in the High Arctic is because field research at that time of year (March, April. May) is so difficult and expensive.

\section{Gyrfalcon Distribution AND Abundance ON ELLESMERE ISLAND}

The Gyrfalcon is apparently widely but sparsely distributed in the Canadian High Arctic Islands, but there is little detailed or specific information on their occurrence and habits. R. D. Muir (unpublished report 1975) assembled information on 15 reported nesting locations or "activity centers" known to have been occupied between 1953 and 1973 on Ellesmere and Axel Heiberg Islands (Table 2), and 
Table 1. Of 23 bird species Parmelee and MacDonald (1960) found on the Fosheim Peninsula of Ellesmere Island, possibly eight of the species below could be considered numerous enough in some situations to be actually or potentially important food for Gyrfalcons:

$\begin{array}{ll}\text { Snow Goose } & \text { Chen caerulescens } \\ \text { Old Squaw } & \text { Clangula hyemalis } \\ \text { Common Eider } & \text { Somateria mollissima } \\ \text { King Eider } & \text { Somateria spectabilis } \\ \text { Rock Ptarmigan } & \text { Lagopus muta } \\ \text { Ruddy Turnstone } & \text { Arenaria interpres } \\ \text { Knot } & \text { Calidris canutus } \\ \text { Long-tailed Jaeger } & \text { Stercorarius longicaudus } \\ \text { Snow Bunting } & \text { Plectophenax nivalis }\end{array}$

Other birds which might be expected to appear on the above list are either absent from the area (such as alcids) or of such low occurrence (shorebirds, except Knot and Turnstone) as to be unimportant to the Gyrfalcon family that Muir and Bird observed.

The total terrestrial mammalian fauna on Ellesmere Island consists of eight species:

$\begin{array}{ll}\text { Muskox } & \text { Ovibos moschatus } \\ \text { Caribou } & \text { Rangifer tarandus pearyi } \\ \text { Arctic Hare } & \text { Lepus arcticus } \\ \text { Lemming } & \text { Dicrostonyx torquatus } \\ \text { Weasel } & \text { Mustela erminea } \\ \text { Arctic Fox } & \text { Vulpes lagopus } \\ \text { Arctic Wolf } & \text { Canis lupus arctos }\end{array}$

between 30-31 May and 20 July 1973 he and D. Bird conducted aerial surveys of them, finding no certain evidence that more than one was occupied by a breeding pair that year (Muir unpublished report 1975). However, it should be noted that these surveys were made from a twin-engine Otter aircraft, which has a high stalling speed and cannot be maneuvered close to cliffs where falcons nest.

In addition to locating one active gyr nest with young in their study area on the Fosheim Peninsula in 1955, Parmelee and MacDonald (1960) listed four, possibly five, locations on Ellesmere where earlier researchers had reported nesting Gyrfalcons; two or three of them apparently are not in Muir's list (Table 2). Nettleship and Maher (1973) reported gyrs from Hazen Lake $\left(81^{\circ} 49^{\prime} \mathrm{N}\right)$ and thought that they were probably breeding there in 1965 and 1966 when Collared Lemmings were abundant enough to support the breeding of a dozen or more pairs of Long-tailed Jaegers (Stercorarius longicaudus) and several pairs of Snowy Owls (Bubo scandiacus) (Maher 1970). An additional active eyrie on the east coast of Ellesmere became publicly known with the release of the BBC nature film, "White Falcon, White Wolf," in 2008. (See, also, Burnham and Newton 2011 for an apparently new nest location in NW Ellesmere at $80.7^{\circ} \mathrm{N}$ and $83.0^{\circ} \mathrm{W}$, K. Burnham pers. comm.).

The exact locations of these 20 or so eyries and activity areas and long-term occupancy rates have not been published, so that it is impossible to draw any conclusions about breeding population size or density. Muir (unpublished report 1975, Table 2) pointed out that from a total of 39 annual observations at 15 probable nesting locations, actual breeding pairs were confirmed only nine times for a total of 17 young. It seems likely that a systematic survey of Ellesmere and Axel Heiberg would yield additional eyries with recent occupancy, but the overall impression now is that nesting gyrs are very sparsely distributed in this region and highly irregular in their breeding performance. 
Table 2. Available data on known or reported Gyrfalcon sites in some High Arctic Canadian Islands.*

\begin{tabular}{|c|c|c|c|c|c|c|}
\hline Site No. & Location & $\begin{array}{l}\text { Previous } \\
\text { History }\end{array}$ & 1971 & 1972 & 1973 & Comments \\
\hline $\begin{array}{l}\text { Special } \\
\text { Project } 1\end{array}$ & Ellesmere & $\begin{array}{l}\text { '56 two fledged } \\
\text { young }\end{array}$ & $\begin{array}{l}\text { Fledged } 3 \\
\text { young }\end{array}$ & $\begin{array}{l}\text { Eggs } \\
\text { destroyed }\end{array}$ & $\begin{array}{l}4 \text { eggs fledged } \\
3 \text { young }\end{array}$ & Apparent long occupancy \\
\hline 2 & Axel Heiberg & $\begin{array}{l}\text { Occupied } \\
\text { during 1960s }\end{array}$ & $\begin{array}{l}3 \text { large } \\
\text { downy young }\end{array}$ & Vacant & Vacant & History of intermittent use \\
\hline 3 & Axel Heiberg & & Vacant & Vacant & $\begin{array}{l}\text { Possibly } \\
\text { occupied }\end{array}$ & Much recent whitewash \\
\hline 4 & Axel Heiberg & & & Occupied & $\begin{array}{l}\text { One adult } \\
\text { present }\end{array}$ & Possible traditional site \\
\hline 5 & Ellesmere & & Vacant & Vacant & Vacant & Possibly vacant many years \\
\hline 6 & Ellesmere & & $\begin{array}{l}\text { One adult } \\
\text { present }\end{array}$ & Vacant & Vacant & $\begin{array}{l}\text { Heavy whitewash possible } \\
\text { fallen rock on ledge, } \\
\text { preventing breeding }\end{array}$ \\
\hline 7 & Ellesmere & & 3 young & & Vacant & $\begin{array}{l}\text { Several heavily white } \\
\text { washed ledges nearby }\end{array}$ \\
\hline 8 & Ellesmere & & & Vacant & Vacant & Probable recent occupancy \\
\hline 9 & Ellesmere & & & & $\begin{array}{l}\text { Reported only, } \\
\text { not found }\end{array}$ & \\
\hline 10 & Ellesmere & & & Vacant & $\begin{array}{l}\text { One adult } \\
\text { present }\end{array}$ & $\begin{array}{l}\text { No birds seen on second } \\
\text { visit }\end{array}$ \\
\hline 11 & Ellesmere & $\begin{array}{l}\text { '24 \& '56 } \\
\text { probably bred }\end{array}$ & Vacant & Vacant & Vacant & Probable recent occupancy \\
\hline 12 & Ellesmere & & & & Vacant & Probable old occupancy \\
\hline 13 & Ellesmere & '55 two young & Vacant & Vacant & Vacant & No recent evidence \\
\hline 14 & Ellesmere & & Vacant & Vacant & Vacant & Probable old occupancy \\
\hline 15 & Ellesmere & $\begin{array}{l}\text { '53 one young } \\
\text { heard. '54 may } \\
\text { have bred. }\end{array}$ & & & $\begin{array}{l}\text { Whitewash } \\
\text { seen-not } \\
\text { visited }\end{array}$ & Status not known \\
\hline
\end{tabular}

* Sources, if other than D. Muir:

$\begin{array}{cll}\begin{array}{c}\text { Site } \\ 1\end{array} & \text { Year } & \text { Source } \\ 2 & 1956 & \text { Thorsteinsson, R. and Tozer, E.T. 1957 } \\ 9 & 1960 \mathrm{~s} & \text { Dr. F. Meuller, McGill University, pers. comm. } \\ 11 & 1971 & \text { R. Kerbes, CWS, pers. comm. } \\ 13 & 1924 & \text { MacMillan, D.B. 1927 in MacDonald 1960 } \\ 15 & 1955 & \text { Parmelee D. and MacDonald S.D. 1960 } \\ & 1953 \& 54 & \text { Bruggerman, P.F. 1953 }\end{array}$

The table indicates places where evidence of Gyrfalcon territories was reported and that breeding activity took place a minimum of nine times out of a possible 39 times. Not fewer than 17 young are known to have been produced from these territories. 
Table 3. Gyrfalcon foods at a nest on Ellesmere Island in the High Arctic as determined from sightings and analyses of pellets (modified from Muir and Bird 1984).

\begin{tabular}{|c|c|c|c|c|c|c|}
\hline \multirow[b]{2}{*}{ Species } & \multicolumn{3}{|c|}{ Prey brought to the nest sightings } & \multirow[b]{2}{*}{$\mathbf{N}$} & \multicolumn{2}{|l|}{ Pellets $^{a}$} \\
\hline & $\mathbf{N}$ & $\%$ occur. & $\%$ wt. & & $\%$ occur. & $\%$ wt. \\
\hline Arctic Hare H $^{b}$ & 32 & 44 & 93.0 & 168 & 23.0 & 82.3 \\
\hline Collared Lemming & 7 & 10 & 0.7 & 298 & 40.8 & 5.1 \\
\hline Short-tailed Weasel & 3 & 4 & 1.7 & 2 & 0.3 & 0.2 \\
\hline Mammal Totals & 42 & 58 & 95.4 & 468 & 64.1 & 87.6 \\
\hline Duck (Anatidae sp.?) & 0 & 0 & 0 & $1^{d}$ & 0.1 & 0.1 \\
\hline Rock Ptarmigan & 0 & 0 & 0 & 14 & 1.9 & 2.9 \\
\hline Ruddy Turnstone & 10 & 14 & 2.3 & 78 & 10.6 & 3.2 \\
\hline European Knot & 9 & 13 & 2.2 & $119^{c}$ & 16.2 & 5.2 \\
\hline Shorebird Totals & 19 & 27 & 4.5 & 197 & 26.8 & 8.4 \\
\hline Snow Bunting & 0 & 0 & 0 & 31 & 4.2 & 0.4 \\
\hline Redpoll (Acanthis flammea) & 1 & 1 & 0.1 & 1 & 0.1 & $<0.1$ \\
\hline Passerine Totals & 1 & 1 & 0.1 & 32 & 4.3 & 0.4 \\
\hline Not identifiede & 10 & 14 & Not incl. & 21 & 2.9 & $0.6^{\dagger}$ \\
\hline Totals & 72 & -- & -- & 732 & -- & -- \\
\hline \multicolumn{7}{|c|}{$\begin{array}{l}\text { a We examined } 606 \text { pellets. } \\
\text { b Calculated at } 1 / 3 \text { average adult weight. } \\
\text { c Includes three occurrences of Sanderling. } \\
\text { d Downy. } \\
\text { e Includes all other species as well as those not ide } \\
\text { f Based on average weights of knot, turnstone, bur }\end{array}$} \\
\hline
\end{tabular}

\section{Gyrfalcon Food Habits on Ellesmere}

The only detailed information on food habits comes from observations at two nests, one on the west side and one on the east side of Ellesmere. At an eyrie near the Eureka weather station on Ellesmere Island ( $80^{\circ} \mathrm{N}$ lat.), Muir and Bird (1984) studied food habits and made observations on behavior from 24 May through the third week of August in 1973. Muir had known about this eyrie since 1954 and first visited it in 1971 (Table 2). It was, therefore, a frequently used site, which is surrounded by barren ground for a radius of about $1.6 \mathrm{~km}$. The Gyrfalcons hunted in a more lushly vegetated lowland about $3 \mathrm{~km}$ distant from the eyrie. The period of observation covered the entire incubation, hatching of four young between 23-27 June, nest departure of three fledglings on 9 August, and part of the fledgling period.
During this time leverets and juvenile Arctic Hares constituted the bulk of the food eaten (93\% of the estimated biomass of food delivered to the nest and $82.3 \%$ of biomass estimated from pellets (Table 3). Very young leverets began appearing on the landscape about the time the female gyr started laying eggs, and the male gyr fed her with these animals during incubation. After the young gyrs hatched, usually only the hindquarters of larger leverets were delivered to the nest, and toward the end of nesting, the female gyr was carrying in the hindquarters of large juvenile hares with considerable difficulty (some of these loads may have been in the range of $1 \mathrm{~kg}$ ). It should be noted that the adult male gyr stopped coming to the eyrie midway during the nestling period, and the female was presumably responsible for all care of the young from that point on, although it cannot be ruled out that he con- 
tinued to provide food to her at some unobserved location.

The leverets are dark gray in color while growing and begin to turn white as they reach adult size in August, so that they are usually quite distinct from adults in color as well as in size, and it is likely that the Gyrfalcons cue in on these features when hunting. [Adult hares can be up to $6 \mathrm{~kg}$ or more]. A notable fact was that the parent gyr continued to deliver dark-colored leverets to her young in August after most of the local young hares had turned white, indicating that the falcon was selectively hunting darker and smaller animals. It also indicated that the overall hare population must have had an extended breeding season with staggered litters over several weeks or some females produced more than one litter, allowing the falcons' prolonged access to a vulnerable food source.

The $\geq 40 \mathrm{~g}$ Collared Lemming apparently was not very common in 1973, as only seven carcasses were found at the eyrie, although it represented the largest number of items in the pellets (298 of $732,41 \%$ occurrence and $5 \%$ of biomass). Most of these pellets could have come from the early stages of the breeding cycle before laying, or even from a previous year. The only other potential mammalian prey were the Short-tailed Weasel and kits of the Arctic Fox. More than one weasel was brought to the 1973 nest, but no fox remains were seen (Table 3).

The Snow Bunting (Plectrophenax nivalis), a 35-40 g bird that sometimes plays an important role in the feeding ecology of Gyrfalcons on Greenland (Salomonsen 1951, Gilg et al. 1997, Booms and Fuller 2003), especially during fall dispersal and migration, was observed frequenting the nesting area and actually nesting close to the Ellesmere eyrie. Although Snow Bunting was not recorded as prey during the nesting period, it did make up a measurable component of the pellet contents $(4.2 \%$ occurrence, $0.4 \%$ biomass, Table 3 ). Again, these buntings may have been captured during the early spring movement onto their nesting grounds or in a previous year.

No Rock Ptarmigan were brought to the eyrie, and the investigators saw none in the region during the entire summer. The 14 occurrences in pellets appeared to be birds mostly in white plumage, probably males, and they likely were taken in the early season before the female gyr began laying.

Although the BBC film (2008) is not a scientific document, it demonstrates that hares were the chief prey of the gyrs filmed at an eyrie in Alexandra Fjord on the east side of Ellesmere. It was apparently a year of high lemming numbers, as Long-tailed Jaegers, Snowy Owls, and Arctic Foxes were all breeding successfully in the area and filmed catching and eating Collared Lemmings. At least one lemming was delivered to the falcon eyrie. There is also mention of a female eider. The film depicts how the female gyr had to struggle to deliver the hindquarters of the older juvenile hares to her cliff-side nest during the latter part of the nesting period.

Parmelee and MacDonald (1960) found two fledged young at a gyr eyrie south of Slidre Fjord (in the Fosheim region) on 22 August 1955. The collected young contained the remains of a Snow Bunting and a juvenile Long-tailed Jaeger. They noted pellets and the remains of Snow Buntings and one juvenile Long-tailed Jaeger and numerous remains of Arctic Hares along the escarpment of the nesting cliff; but they found no evidence of ptarmigan, despite the fact that they estimated the breeding density of ptarmigan on the Fosheim Peninsula that year to be about one pair per 256 ha. Bruggemann (in Parmelee and MacDonald 1960) saw few ptarmigan in the same region in 1953, stating that he thought only four to five pairs nested. A young gyr shot at Eureka in September of 1955 contained remains of four Snow Buntings. 


\section{COMParison OF THREE High Arctic Gyrfalcon Populations}

Ellesmere and Canadian High Arctic Islands.-From what we know so far, it appears that although suitable nesting locations are widespread throughout the Queen Elizabeth Islands, the actual use of these areas is limited both in time and space to those few situations in any given year when the abundance of prey is sufficient to support a breeding pair and their young, at least from the beginning of April to the end of August. It seems clear that the bulk of food (more than $80 \%$ by weight) that parents feed to their young are the leverets of Arctic Hare, weighing from $100 \mathrm{~g}$ at birth to $2.7 \mathrm{~kg}$ by 8 August on Axel Heiberg Island (Parker 1977; see also Anderson and Lent 1977 for comparable growth rates of Lepus othus in western Alaska). Hares appear to be more abundant on Ellesmere and Axel Heiberg Islands than in other parts of the High Arctic owing to the richer vegetative growth (particularly Salix arctica), found in certain areas such as the Lake Hazen Thermal Trough (Nettleship and Maher 1977, France 1993) and the Fosheim Peninsula (Parmelee and MacDonald 1960, Muir and Bird 1984). Even so, there can be considerable fluctuation in numbers from year to year (see Mech 2007 for an extreme example on the Fosheim Peninsula resulting from die-offs from abnormally early snow cover in August of 1997 and 2000).

The Collared Lemming, which seems to be more cyclic than the hare on Ellesmere, at least historically, could be a significant prey item for Gyrfalcons in some years, as it is known to achieve densities that produce both numerical and functional reproductive responses in Longtailed Jaegers and Snowy Owls (Maher 1970, BBC film 2008), and presumably also in Short-tailed Weasels and Arctic Foxes (see Gilg et al. 2003). In some situations lemmings could substitute for hares as the principal prey. Other prey used in the latter part of the nesting season include shorebirds, Long-tailed Jaeger, occasional ducks and geese, some ptarmigan, and Snow Buntings especially when the gyrs are dispersing or migrating in late August and September.

The prey that Gyrfalcons depend on in the critical early period of breeding (April to midMay) before they lay eggs is still speculative owing to lack of direct observations. Although Gyrfalcons are quite capable of killing and eating adult hares (Poole and Boag 1988), at least the smaller ones in the $\pm 3 \mathrm{~kg}$ range, it seems unlikely that the mated males would do so consistently, as they prefer to transport smaller items to feed their females (ptarmigan breasts are optimal). There is, however, an intriguing caption to a picture on the Canadian National Museum of Nature's website, "Ukalig the Arctic Hare," that states without attribution: "Migrating Gyrfalcons might have been a major cause of the decline of the Arctic Hare... populations at Sverdrup Pass...in the winter of 1986-87." This statement implies that gyrs were feeding on adult-sized hares in wintertime in the interior of Ellesmere Island above $79^{\circ} \mathrm{N}$ lat. Scientific verification of this possibility is needed. David Gray (1993), a researcher who has spent many years studying the Arctic Hare on Ellesmere, provided an instructive account of how the hares in Sverdrup Pass protect themselves from bad weather and predators during winter but made no mention of observations on Gyrfalcons.

It seems possible that lemmings provide most of the food in the early breeding season, when they are abundant following vigorous winter reproduction under the snow, combined with some ptarmigan, which occur in small flocks at that time. This possibility would depend on how frequently lemmings are exposed above snow cover in April and May. Flocks of male Snow Buntings begin appearing on Ellesmere in mid-April, and they could well add to the available food supply, but they may not be as vulnerable to capture as young-of-the-year and molting adults are in August, although adult buntings were fearless in perching close to the gyrs at their 1973 nest (D. Bird, pers. comm.). 
Another possibility is that at coastal eyries the falcons may hunt water birds out over the polynyas and open leads that surround much of Axel Heiberg and Ellesmere Islands, such as the Hell Gate Polynya (Mallory and Gilchrist 2005) and the North Water Polynya between NW Greenland and Ellesmere, but so far, no nesting territory has been found in this region where Gyrfalcons concentrate on seabirds for their food. Except for Devon Island, there are no breeding colonies of alcids (Dovekies, murres) in the Queen Elizabeth Islands.

How much prey would it take to provision a pair of gyrs adequately for reproduction during the 45 or so days from establishment of territory to laying of eggs? Based on estimates of daily food requirements (see Cade et al. 1998, Booms et al. 2008), the male gyr would need to catch at least one ptarmigan per day (45 for the period), or 10 lemmings or Snow Buntings per day ( $450 \mathrm{~g}$ each for the period) to feed his mate and himself. If the male gyr hunted only ptarmigan, he would likely need to encounter at least one flock averaging five or six individuals each day. If lemmings occurred at a density of 10 animals per ha (Gilg et al. 2003), the gyr would remove the equivalent of 45 ha of lemmings. To take the required number of Snow Buntings the gyr would likely have to encounter 10 flocks of several dozen to several hundred buntings each day. None of these hypothesized situations appears unrealistic under favorable conditions. The gyrs would be particularly advantaged in years when two or more of these prey populations occurred in high abundance at the same time, and such fortuitous coincidences may often determine where and when Gyrfalcons nest in the High Arctic.

Northeast Greenland.- The early investigations of this region, from Scoresbysund north through Germania Land $\left(70^{\circ}\right.$ to $\left.77^{\circ} \mathrm{N}\right)$ clearly indicated the importance of the Collared Lemming in the diet of the Gyrfalcon, although ptarmigan were considered to be important too (Salomonsen 1951).
It appears that ptarmigan were much more abundant in the early decades of the 1900s than they are currently. The following quotes and generalizations come from Salomonsen's (1950) account of the Rock Ptarmigan in his monograph, Birds of Greenland. "The Ptarmigan is a common breeding-bird throughout the whole of Greenland, occurring as far north as firm land extends into the Polar Sea and apparently being as common on the North-coast as in the more favored areas in S. Greenland." Winter flocks may consist of as few as two to five birds, but usually they number 50 to 100 individuals. In peak years, flocks of up to 1,000 are seen. Peak years occur about every 10 years. "In years when the numbers are at peak the country abounds in ptarmigan. Tens of thousands are taken at each of the settlements, and the trappers of NE Greenland likewise account for enormous numbers." Particularly big peaks occurred in 1890-91 in S. Greenland, 1929-30 in NE Greenland, and throughout the whole country in 1948-49. There are "mass migrations" south in peak years. The ptarmigan leave northern Greenland in the "dark months" of November to January and arrive in S. Greenland in February before the sun appears above the horizon. Reports that Vibe (1967) analyzed also indicated that ptarmigan cycled in numbers every 11 years between 1886 and 1954 in West Greenland. No such indications of abundance as those summarized above have been reported since the 1950s.

In contrast, recent winter surveys from 1977 to 2004 by teams of two men on dog sledges, mostly from mid-February to early June, indicate sparse numbers of ptarmigan throughout NE Greenland with no evidence of cycles or much synchrony in numbers among regions (Hansen et al. 2008). Each year six sledge teams covered approximately $20,000 \mathrm{~km}$ of coastline. The annual numbers counted in the three best studied sub-regions ranged from 0 to 107 ( $\mathrm{av}=13.8), 0-42$ (av =7.7), and 0-103 (av =11.9). Even the highest reported numbers are small for such large sub-regions. Ptarmigan are now reported to be sparse to uncommon 
throughout most of Greenland, even in the south. For example, Boertmann's (1994) tally of eight reported breeding densities since 1967 range from about one pair per 56 ha to one pair per 607 ha. Curiously, this list includes a figure of one pair per 167 ha on Traill Island in 1990, which was reported to be a peak year for ptarmigan). By comparison, in Iceland, Nielsen (1999) reported average territorial male densities that ranged from one male per 4.6 to 5.6 ha (peak years) to one male per 16.8 to 19.2 ha (low years) from 1981 through 1997.

Recent observations carried out incidental to caribou surveys by helicopter in West Greenland suggest a rosier picture of ptarmigan abundance in regions from roughly $69^{\circ} \mathrm{N}$ to $61^{\circ} \mathrm{N}$ (Cuyler et al. 2009). Random survey transects each $7.5 \mathrm{~km}$ long, and $200 \mathrm{~m}$ wide for ptarmigan, were conducted at a height of $15 \mathrm{~m}$ above ground level in four regions in March of 2005 or 2006.

In the North region between Nordre Strømfjord and the Sukkertopen Ice Cap $(26,000$ $\mathrm{km}^{2}$ ) there were 60 transects with a total area of $90 \mathrm{~km}^{2}$, in which 605 ptarmigan were counted (density of one bird per 180 ha in the high density caribou zone, 110 ha in the low density caribou zone). In the Central region between the Sukkertoppen Ice Cap and Godthåbsfjord $\left(15,362 \mathrm{~km}^{2}\right)$ in March of 2005 there were 54 transects with a total area of 81 $\mathrm{km}^{2}$, in which 132 ptarmigan were observed with densities of one ptarmigan per 658 to 521 ha in the high and low caribou areas respectively. In March of 2006, in the South region (two areas) from Godthåbsfjord to Frederikshåb $\left(13,473 \mathrm{~km}^{2}\right)$ there were 64 transects covering $96 \mathrm{~km}^{2}$ ), in which 189 ptarmigan were observed with densities ranging from one in 413 ha to one in 820 ha.

The authors then calculated what they refer to as an "index of abundance" for each of the surveyed areas, to be used for comparative purposes among regions and years. The authors did not explain how they derived such large extrapolations of the basic survey counts, and it seems wiser for now to rely on what can be inferred from a direct consideration of the transect counts, which are numerous enough to stand on their own merits. These results show that Rock Ptarmigan in the central and southern parts of West Greenland appeared to be more common in 2005-06 than generally reported in other parts of the country. To what extent this difference in abundance is influenced by comparing data from aerial helicopter surveys to those from ground surveys remains an open question. It may be significant that most of the observed flocks were under 16 birds and none was greater than 25-27, in comparison to the much larger flock sizes that Salomonsen summarized for earlier years. Furthermore, the total annual hunter harvest of Rock Ptarmigan in Greenland averaged between 40 to 50 thousand birds in the period 1996 to 2002 but fell to around 20 thousand in 2003 to 2005 (Cuyler et al. 2009).

To summarize the evidence for an apparent long-term, historical (and continuing) decline in the Rock Ptarmigan populations of Greenland and the Canadian High Arctic Islands: (1) historical reports down into the 1950s paint a picture of winter flocks numbering in the 50 to 100 bird range, or even much higher in peak years, and breeding populations that were widespread throughout both the High and Low Arctic regions and that underwent regional and multi-regional cycles of abundance and scarcity with periods of 10 to 11 years. Hunters shot tens of thousands of ptarmigan around their villages. No indicators of such abundance have been reported since the 1950s. 2. Currently and for the past several decades field observers have reported few remains of ptarmigan at Gyrfalcon nests in the High Arctic. 3. Few ptarmigan are noted in the breeding season, and major population peaks have not been recorded since the 1950s. 4. Winter flocks are now typically under 25 birds, and the majority of flocks are under 10 birds, even in central-west Greenland where helicopter surveys in March of 2005 and 2006 revealed 
substantial numbers. 5. Late winter sledge teams of observers working over the period 1977 to 2004 in NE Greenland found extremely low numbers of ptarmigan, no evidence of a population cycle, and little annual synchrony in numbers among different regions. 6. The national hunter harvests of ptarmigan in Greenland fell from 40 to 50 thousand per year in 1996 to 2002, to 20 thousand in 2003-2005.

Why are ptarmigan apparently declining in NE Greenland and elsewhere in the High Arctic? There may be multiple impacts from climate change, including the influence of warming on nutritional deterioration of the plant foods that ptarmigan eat, especially Salix arctica, Dryas spp., and Vaccinium spp., resulting in reduced reproduction and perhaps adult viability (Berg et al. 2008). Selås et al. (2011) found that certain grouse and microtine rodents increased in number about two years following a peak in the seed crop of Bilberry (Vaccinium myrtillus) because of reduced chemical feeding deterrents in the Bilberry when growing at lower temperatures. Since the Bilberries are less exhausted after a high seed crop in or after warm summers, they rebuild their chemical defenses more rapidly and become unpalatable to herbivores. Population indices of grouse and microtine rodents were negatively related to summer temperatures in southern Norway in the previous year or two. Willow Ptarmigan chick production was also negatively related to summer temperatures in the previous two years in five areas of Norway. The authors concluded that high summer temperatures could limit the reproduction of grouse through its effect on Bilberry plants and that a warm climate thus adversely affects populations of grouse, and presumably other herbivores that feed on Bilberry.

Arctic Hares also occur in NE Greenland, but they are much less common than on Ellesmere Island. Snow Buntings were also recognized as an important source of food for gyrs, particu- larly in the late season and during migration in August through September (Salomonsen 1950).

Salomonsen (1951) considered the Gyrfalcon to be "an abundant breeding bird" in the Scoresbysund region, along the Liverpool Coast, and all the way into Germania Land, based mainly on the writings of Pedersen, Manniche, Bird, Finch, Kalthoff, and Løppenthin, estimating "about 40 breeding pairs in the interior fjord country [at Scoresbysund] and 25 pairs at Liverpool coast." The large number of Gyrfalcons shot and observed during migration at Danish weather stations, such as the one near Kap Tobin (Scoresbysund), indicate that Gyrfalcons were once more abundant in NE Greenland than at present. Salomonsen (1951) cited an instance in 1928, "which was a pronounced peak year of the lemming," of 250 falcons that were shot at the Scoresbysund settlement and a similar number farther north at MacKenzie Bay, where only four specimens were taken in 1930-31; and in 1937 between 200 and 300 white falcons passed Scoresbysund in the first 17 days of September.

Such numbers have not been confirmed in recent decades (Meltofte 1975, 1977, 1981, Boertmann 1994). In retrospect the number of "pairs" that Salomonsen specified likely refer to the number of known or estimated eyries or "activity centers," many of which would not have been occupied in any given year. An examination of Alwin Pedersen's original publications in Danish (W. Mattox pers. comm.) reveals no indication of how he determined 40 pairs for Scoresbysund and 25 pairs for the Liverpool coast. He mentioned only one eyrie located on the Neill Klinter formation on the west side of Hurry Fjord just north of Cape Stewart, first reported by E. Bay in 1891-92. It was apparently still active in 1999 (see Cade and Nielsen 2011, this volume).

In 1999 Cade and Nielsen (2011) conducted a helicopter survey of falcon eyries in about $6,000 \mathrm{~km}^{2}$ of the Jameson Plateau, the largest 
ice-free area in the Scoresbysund region, and a dog-sledge trip in early June to the Liverpool Coast from Ittoqqortoormitt to Cape Höegh, about $30 \mathrm{~km}$ of the Liverpool Coast. They found four active nests with incubating females on the Jameson plateau, and a skiing colleague found one on the Liverpool Coast. These low numbers are consistent with the findings of $\mathrm{H}$. Meltofte and other investigators working farther north in Germania Land. Also, in 2004 and 2005 researchers from The Peregrine Fund trapped and banded Gyrfalcons at Kap Tobin, Scoresbysund from early September to mid-October, capturing 38 falcons the first year and 87 the second. It is not known whether these were good or bad years for reproduction, but the trapping results indicate that a fair number of Gyrfalcons still pass Scoresbysund in autumn.

In connection with a long-term project beginning in 1988 on Traill Island $\left(72^{\circ} 30^{\prime} \mathrm{N}\right)$ on the coast of NE Greenland to study the Collared Lemming and its principal predators (Gilg 2003, Gilg et al. 1997), these researchers also examined the food habits of a pair of Gyrfalcons at an eyrie on Ymer Island $\left(73^{\circ} 05^{\prime} \mathrm{N}\right)$. They collected in August of 1990, 1992, and 1995 and subsequently examined 274 pellets (363 prey) and 15 prey remains representing 14 different species (Gilg et al. 1997). The presence in the pellets of white lemming fur and forepaws with double claws indicated that the pellet samples reflected food habits from early spring before laying to the fledgling period. The year 1990 was a "high peak" year for lemmings, followed by a "deep depression" in 1992, while collection in 1995 followed a lemming peak in 1994. The pair of gyrs bred successfully in 1990 and 1995 but failed in 1992.

The volume of lemming remains in pellets was nearly $50 \%$ of the totals in 1990 and 1995 , but in 1992 passerine birds, mostly Snow Buntings, predominated at about $50 \%$ of total volume, and ptarmigan were also included. Other species of prey, including hare, were about the same percent of volume in all three years. The authors concluded that in addition to the well-known numerical response of the Gyrfalcon to prey density, there can also be a functional response, which in this instance was inadequate to support successful breeding. Unfortunately, the authors did not publish any of the actual data or perform the statistical tests needed to support their inferences and conclusions, so that the significance of their study remains problematic. One wonders whether or not the apparent dependence of this pair of Gyrfalcons on lemming "highs" for successful reproduction was the usual, historically grounded situation in NE Greenland, or rather represented a new, perhaps inadequate, adjustment to an impoverished food base owing to the reduced number of ptarmigan in the region.

To summarize, the current trophic conditions for Gyrfalcons in NE Greenland appear to be compromised by a general, region-wide reduction in the number of ptarmigan. Historically ptarmigan reached periodic peaks of high abundance. One may suppose that these peaks sometimes corresponded to peaks in the lemming populations, and perhaps also in hare populations, resulting in unusually good falcon reproduction and high numbers of Gyrfalcons observed in migration along the East Coast and wintering in South Greenland at places such as Angmagssalik (Salomonsen 1951). Now ptarmigan apparently can only serve as a secondary source of food, and the Gyrfalcons have had to rely more on other species such as Collared Lemmings and Snow Buntings - or on Dovekies at some eyries on the Liverpool Coast. Hares apparently are never abundant enough in NE Greenland to be significant in the diet.

In the early season before hatching, the gyrs must now depend on lemmings and whatever ptarmigan happen to be present, and perhaps on Snow Buntings after mid-April. Obviously, conditions at some nesting territories have allowed Gyrfalcons to make successful transitions to these new circumstances but for how long? Moreover, how many have not done so? 
To fill out the High Arctic picture, the situation for Gyrfalcons in Perry Land, northernmost Greenland, appears to be very similar to that of NE Greenland (Johnsen 1953). Suitable nesting sites are widely distributed through this region on rocky cliffs both coastally and inland, but breeding is limited by the sporadic abundance of food at particular territories. Johnsen (1953) listed some 20 locations where gyrs were sighted, but only three were observed to be occupied by nesting pairs and perhaps an additional three or four showed signs of previous use (well marked nest-sites). He concluded that lemmings were the main food taken by gyrs in this region, but ptarmigan, Snow Buntings, and young hares were also important. Fall migration is conspicuous, beginning in late August, and likely comes mainly down the east coast of Greenland.

\section{Thule District, Northwest Greenland.-} Although quite a bit of research on Gyrfalcons has been carried out in the Thule region since 1993 (Burnham 2007), there has never been a major, quantitative study of their food habits. Burnham (2007) summarized what he found at 29 nestings (14 known eyries) from 1994 to 2005. Dovekie remains occurred at a preponderance of nests (79\%) and were the only prey found at 14 nests, nearly half. Rock Ptarmigan were found at eight nests, Black Guillemot (Cepphus grylle) at five, Arctic Hare at five, Oldsquaw (Clangula hyemalis) at three, songbirds and Black-legged Kittiwakes (Rissa tridactyla) at two, and Common Eider (Somateria mollissima) and Snow Goose (Chen hyperborea) at one each. One eyrie far from the coast had mostly the remains of hare leverets and songbirds.

As there are no lemmings in this region, the only prey available to gyrs in the early part of the breeding season, before the Dovekies arrive at their nesting cliffs in mid-May and the tundra nesting migrants arrive, are ptarmigan, Snow Buntings, and hares. The extent to which gyrs might hunt hares and buntings in April and May is not known, nor do we really know much about the abundance of these species in the Thule region at that time of year. It seems likely that most pairs of gyrs in the Thule region (Cape York to Etah) depend upon the uncertain abundance of Rock Ptarmigan for establishing their territories and allowing the males to provision their mates with enough food to induce them to lay eggs, followed by feeding the hatched young mainly on the superabundant Dovekies (Burnham 2007). Some coastal pairs situated close enough to open water might manage by taking small gulls, guillemots, Dovekies, and ducks, but most of these species, except the Dovekie, would have to be dismembered before the male could deliver parts to the female, so that the energetic cost, including a long flight, might outweigh the benefit in this situation, as would also be the case for adult Arctic Hares.

Historically many pairs of gyrs nesting further south on the west coast of Greenland (e.g., Uummannaq Bay) also depended heavily on seabirds (kittiwakes, gulls, murres, guillemots) for feeding their nestlings, after starting the breeding season on a diet of ptarmigan. Now many of the seabird colonies no longer exist, and breeding Gyrfalcons appear to be less common than they once were (Salomonsen 1951, Burnham et al. 2005). Also, the switching from ptarmigan in the early season to the leverets of Arctic Hare in mid-season, and then to juvenile songbirds at the end of summer has been well documented for Gyrfalcons nesting in the Low Arctic tundra around Søndre Strømfjord, West Greenland (Booms and Fuller 2003) and in the central Canadian Arctic (Poole and Boag 1988).

\section{Winter Distribution AND Foraging of High Arctic Gyrfalcons}

Although this paper mainly concerns trophic relations during the nesting season, a few remarks are needed to complete the annual cycle of dietary changes among the High Arctic gyrs, because these falcons have also proved to be somewhat unique in the ways 
they survive through the winter in anticipation of breeding.

Although it has long been known that the High Arctic gyrs are migratory, and that white gyrs, presumably from Greenland, appear in Iceland during winter (Nielsen and Pétursson 1995), and Mosbech and Johnson (1999) saw 16 Gyrfalcons on the sea ice in southern Baffin Bay and the Davis Strait, the full extent of these fall and winter movements have only just come to light as the result of radio-tracking 48 gyrs with satellite transmitters from four trapping locations in Greenland (Thule District at ca. 75.9 to $77.6^{\circ} \mathrm{N}$, Kangerlussuaq at $65.5^{\circ}$ to $67.5^{\circ} \mathrm{N}$, and Manniitsog, $65.4^{\circ} \mathrm{N}$ on the westcentral coast, and Scoresbysund on the east coast at $70.4^{\circ} \mathrm{N}$; Burnham and Newton 2011). The authors provide a very full account of the various patterns of movement and residency among these gyrs in winter, and it is only necessary to summarize the salient features here.

They found that some gyrs from Ellesmere Island and Thule District traveled southward over the sea ice on the Canadian side of Baffin Bay and Davis Strait but then turned eastward to winter in the open fjords of SW Greenland where millions of seabirds (alcids, gulls) and sea ducks concentrate in food-rich maritime waters. Others came south along the West Coast of Greenland, some of which may have followed small flocks of ptarmigan, which move into SW Greenland for the winter and then return north beginning in March. Some gyrs established enduring winter home ranges, some others switched from one home range to another (up to four times), and still others were more or less nomadic, wandering up and down the coast or out over open water for days at a time.

The authors also found significant differences in the winter home range sizes between falcons tagged on the West Coast ( 385 to $6,657 \mathrm{~km}^{2}$ ) and the East Coast $\left(26,810\right.$ to $\left.63,647 \mathrm{~km}^{2}\right)$. The latter are among the largest home ranges measured for any bird and apparently relate to the fact that the gyrs of this region range widely out to sea, spending up to 40 consecutive days away from land. They evidently use the edge of the pack ice and icebergs for perching and hunting, again foraging on the numerous marine birds that concentrate in these waters in winter.

The various patterns of movement and winter occupancy that Burnham and Newton (2011) described for these falcons appear to be individual strategies for foraging on regionally abundant but widely dispersed prey. Some of these options are no doubt better for survival than others, particularly the energetically less expensive alternatives.

Generally biologists tend to think of the harsh arctic winter as the toughest time for the survival of Gyrfalcons, but this assumption may not be true for gyrs hunting abundant maritime and marine birds. First, gyrs are well adapted to survive in the cold, with highly insulative plumage and likely a low thermal neutral zone, perhaps with some tolerance for hypothermia, and well-developed shelter-seeking behavior that allows them to weather prolonged storms (Cade 1999). Once an individual falcon has located a concentration of sea birds it may well feed more or less at will for days on end.

If so, could it be that these wintering maritime and marine feeders arrive back on their breeding grounds in April and May in a higher state of nutritional fitness than, say, their counterparts that have spent the winter in mid-continental habitats with poorer food resources? The returning females could then build up their reserves rather quickly for egg production and laying, making the apparently shorter breeding season in the High Arctic easier to accomplish. Studies on the reproductive physiology of Gyrfalcons could help us understand these possibilities.

\section{Conclusion}

At least at the present time, owing to the low number of ptarmigan, Gyrfalcons in High Arctic locations have had to take advantage of 
other prey to the extent they can. Where Collared Lemmings occur and achieve periodic peaks of abundance following winter reproduction under the snow, this 40-50 g rodent may be an adequate substitute for ptarmigan in the early part of the breeding season-and later as well, depending on when the lemming die-off occurs. It is unclear, however, as to how available lemmings are to Gyrfalcons when winter snow and nests provide safe cover. They are probably most vulnerable to capture during spring melt-off.

Snow Buntings, which become available around the middle of April and which do not have marked annual fluctuations in numbers, could be a secondary food at this time, but most evidence indicates that their importance in the gyr's annual diet occurs in August and September, when the young of the year are easy prey for recently fledged falcons. It is problematic whether or not the adult Arctic Hare $(3-6 \mathrm{~kg}$ ) or any other species could fill this early season role effectively. The primary role of the hare, when and where abundant, is during the period June-August when the young gyrs are in the nest and their parents can catch leverets. As the breeding season progresses, lemmings, young Arctic Hares, seabirds, especially Dovekies, ptarmigan, passerines, and to varying degrees other species of birds can make up an adequate diet for successful reproduction, depending on local circumstances.

Dependence on species that cycle or fluctuate from low to high numbers (lemmings, hares, ptarmigan) could seriously interfere with the survivability of Gyrfalcon populations if climate change were to reduce the amplitude or increase the period between peak years of abundance of these basic arctic herbivores (Gilg et al. 2009). The trophic relations of the High Arctic gyrs are further complicated by the fact that there can be up to four or five major switches in prey utilization during the annual cycle - from ptarmigan or lemmings in the early breeding season, to hares or Dovekies in summer, to Snow Buntings and other song birds during fall migration, to seabirds or ptarmigan in winter, and back to ptarmigan or lemmings in spring. Thus, there are multiple opportunities for climate change to interfere with these processes. The extent to which there can be overlap in switching from an early season source of food to a later one may largely determine breeding success or failure. If the early source becomes depleted before the second source becomes available, the reproductive effort will likely fail. Changes in the phenology of these prey dynamics could be influenced by global warming, either to the benefit or detriment of the falcons. The falcons might also change the timing of their breeding to fit the changing circumstances of prey abundance. There is much to be learned about how such adjustments will play out in the next 50 to 100 years.

\section{ACKNOWLEDGMENTS}

We would like to recognize J. Dalton Muir, who formerly worked for the Canadian Wildlife Service for several seasons between the 1950s and 1970s doing field work on Ellesmere and other Canadian High Arctic islands, where he made observations on the occurrence of Gyrfalcons and their prey. His notes and reports provided the original stimulus for writing this paper. Grainger and Terry Hunt provided numerous helpful suggestions for improving the manuscript. David Gray, Ross Glenfield, David Mech, and Mark Mallory considerably increased our understanding of ecological conditions in the Canadian High Arctic.

\section{Literature Cited}

Anderson, H. L., And P. C. Lent. 1977. Reproduction and growth of the tundra hare (Lepus othus). Journal of Mammalogy 58:53-57.

BerG, T. B., N. M. SChMidt, T. T. Høye, P. J. Aastrup, D. K. Hendrichsen, M. C. FORCHHAMMER, AND D.R. KLEIN. 2008. High-arctic plant-herbivore interactions 
under climate influence. Advances in Ecological Research 40:275-298.

Boertmann, D. 1994. An annotated checklist to the birds of Greenland. Medelelser om Grønland 38:1-63.

Booms, T. L., T. J. Cade, And N. J. Clum. 2008. Gyrfalcon (Falco rusticolus). In A. Poole (Ed.). The Birds of North America (Revised) Online. Cornell Laboratory of Ornithology, Ithaca, New York, USA. Retrieved from The Birds of North America Online database: http://bna.birds. cornell.edu/bna/species/114

Booms, T. L., AND M. R. Fuller. 2003. Gyrfalcon diet in central west Greenland during the nesting period. Condor 105:528-537.

BURNHAM, K. K. 2007. Inter- and intraspecific variation of breeding biology, movements, and genotype in Peregrine Falcon Falco peregrinus and Gyrfalcon Falco rusticolus populations in Greenland. Doctoral Dissertation. Wolfson College, University of Oxford, Oxford, UK.

Burnham, K. K., AND I. Newton. 2011. Seasonal movements of Gyrfalcons Falco rusticolus include extensive periods at sea. Ibis 153:468-484.

Burnham, W., K. K. Burnham, AND T. J. CADE. 2005. Past and present assessments of bird life in Uummannaq District, West Greenland. Dansk Ornithologisk Forenings Tidsskrift 99:196-208.

CADE, T. J. 1999. The Gyrfalcon's adaptations for survival in arctic regions. Pages 55-68 in E. Ford. Gyrfalcon. John Murray, London, UK.

CAde, T. J. , P. Koskimies, ANd Ó. K. Nielsen. 1998. Falco rusticolus Gyrfalcon. Birds of the Western Palearctic Update 2(1):1-25.

CAdE, T. J., AND Ó. K. NiELSEN. 2011. Surveys for Gyrfalcons in the Scoresbysund region of northeast Greenland in 1999. In R. T. Watson, T. J. Cade, M. Fuller, G. Hunt, and E. Potapov (Eds.). Gyrfalcons and Ptarmigan in a Changing World. The Peregrine Fund, Boise, Idaho, USA. http://dx.doi. org/10.4080/gpcw.2011.0402
Cuyler, C., M. Rosing, H. Mølgaard, R. Heinrich, J. Edgede, and L. MathAEUSSEN. 2009. Incidental observations of muskox, fox, hare, ptarmigan \& eagle during caribou surveys in West Greenland. Technical Report No. 75, Greenland Institute of Natural Resources, Nuuk, Greenland.

France, R. L. 1993. The Lake Hazen Trough: a late winter oasis in a polar desert. Biological Conservation 63:149-151.

Gilg, O., I. Hanski, AND B. Sittler. 2003. Cyclic dynamics in a simple vertebrate predator-prey community. Science 302:866-868.

Gilg, O., B. Sittler, ANd B. SABARd. 1997. Numerical and functional response of Gyrfalcon (Falco rusticolus) to lemming (Dicrostonyx groenlandicus) fluctuations in NE Greenland. Pages 5-6 in T. B. Berg, M. C. Forchhammer, and E. Skytte (Eds.). Arktisk Biologisk Forskermode VI. Danish Polar Center, Copenhagen, Denmark.

Gilg, O., B. Sittler, AND I. Hanski. 2009. Climate change and cyclic predator-prey population dynamics in the high Arctic. Global Change Biology 15:2634-2652.

GRAY, D. R. 1993. Behavioural adaptations to arctic winter: Shelter seeking by Arctic Hare (Lepus arcticus). Arctic 46:340-453.

Hansen, J., H. Meltofte, and T. T. Høye. 2008. Population fluctuations in Rock Ptarmigan in high-arctic Greenland. Dansk Ornithologisk Forenings Tidsskrift 102:319-324.

JoHNSEN, P. 1953. Birds and mammals in Perry Land in northern Greenland. Meddelelser om Grønland 128:1-135.

Koskimies, P., AND S. SulKava. 2011. Diet of the Gyrfalcon (Falco rusticolus) in northern Fennoscandia. In R. T. Watson, T. J. Cade, M. Fuller, G. Hunt, and E. Potapov (Eds.). Gyrfalcons and Ptarmigan in a Changing World. The Peregrine Fund, Boise, Idaho, USA. http://dx.doi.org/ 10.4080/gpcw.2011.0400 
MAHER, W. J. 1970. Ecology of the Longtailed Jaeger at Lake Hazen, Ellesmere Island, Canada. Arctic 23:112-129.

Mallory, M. L., AND H. G. Gilchrist. 2005. Marine birds of the Hell Gate Polynya, Nunavut, Canada. Polar Research 24:8793.

Mech, L. D. 2007. Annual arctic wolf pack size related to arctic hare numbers. Arctic 60:309-311.

Meltofte, H. 1975. Ornithological observations in northeast Greenland between $76^{\circ} 00^{\prime}$ and $78^{\circ} 00^{\prime}$ N. lat., 1969-71. Meddelelser om Grønland, Bioscience 191: 172.

Meltofte, H. 1977. Ornithological observations in Germania Land, Northeast Greenland, 1974. Dansk Ornithologisk Forenings Tidsskrift 71:81-94.

Meltofte, H., M. Elander, and C. HJort. 1981. Ornithological observations in northeast Greenland between $74^{\circ} 30^{\prime}$ and $76^{\circ} 00^{\prime}$ N. lat., 1976. Meddelelser om Grønland, Bioscience 3:1-53.

Mosbech, A., And S. R. Johnson. 1999. Late winter distribution and abundance of seaassociated birds in south-western Greenland, Davis Strait, and southern Baffin Bay. Polar Research 1:1-17.

Mossop, D. H. 2011. Long-term studies of Willow Ptarmigan and Gyrfalcon in the Yukon Territory: A collapsing 10-year cycle and its apparent effect on the top predator. In R. T. Watson, T. J. Cade, M. Fuller, G. Hunt, and E. Potapov (Eds.). Gyrfalcons and Ptarmigan in a Changing World. The Peregrine Fund, Boise, Idaho, USA. http:// dx.doi.org/10.4080/gpcw.2011.0206

Muir, D., AND D. M. BIRD. 1984. Food of Gyrfalcons at a nest on Ellesmere Island. Wilson Bulletin 96:464-467.

Nettleship, D. N., AND W. J. Maher. 1973. The avifauna of Hazen Camp, Ellesmere Island, N.W.T. Polarfurschung 43:66-74.
Nielsen, Ó. K. 1999. Gyrfalcon predation on ptarmigan: Numerical and functional responses. Journal of Animal Ecology 68:1034-1050.

NiELSEN, Ó. K. 2011. Gyrfalcon population and reproduction in relation to Rock Ptarmigan numbers in Iceland. In $\mathrm{R}$. T. Watson, T. J. Cade, M. Fuller, G. Hunt, and E. Potapov (Eds.). Gyrfalcons and Ptarmigan in a Changing World. The Peregrine Fund, Boise, Idaho, USA. http://dx.doi. org/10.4080/gpcw.2011.0210

Nielsen, Ó. K., AND G. PÉTuRsSON. 1995. Population fluctuations of gyrfalcon and rock ptarmigan: Analysis of export figures from Iceland. Wildlife Biology 1:65-71.

NySTRÖM, J., J. EKENSTEDT, J. ENGSTRÖM, AND A. Angerbjörn. 2005. Gyr Falcons, ptarmigan and microtine rodents in northern Sweden. Ibis 147:587-597.

PARKer, G. R. 1977. Morphology, reproduction, diet, and behavior of the arctic hare (Lepus arcticus) on Axel Heiberg Island, North West Territories. Canadian FieldNaturalist 91:8-18.

Poole, K. G., AND D. A. BoAg. 1988. Ecology of Gyrfalcons, Falco rusticolus, in the central Canadian Arctic: Diet and feeding behavior. Canadian Journal of Zoology 66:334-344.

Parmelee, D. F., and S. D. Macdonald. 1960. The birds of west-central Ellesmere Island and adjacent areas. National Museum of Canada Bulletin 222:1-229.

SALOMONSEN, F. 1950-51. Grønlands Fugle/The birds of Greenland. 2 vols. Munksgaard, Copenhagen, Denmark.

SelÅs, V., G. A. Sonerud, E. Framstad, J. A. KÅlÅs, S. Kobro, H. Pedersen, T. Spids $\varnothing$, AND Ø. WIIG. 2011. Climate change in Norway: Warm summers limit grouse reproduction. Population Ecology 53:361-371.

VIBE, C. 1967. Arctic animals in relation to climatic fluctuations. Medelelser om Grønland 170(5):221. 